\title{
PERSONNEL SELECTION - BASIS OF TECHNOLOGY OF IT'S QUALITY MANAGEMENT
}

The article is devoted to the problems of personnel selection. It states that professional selection is the most important part of the hiring of employers; it mainly determines the effectiveness of personnel management. Therefore, the modern organizations give appropriate attention to the personnel selection.

The article stresses that the priority tasks of increasing the efficiency of functioning of executive and management structures are: to equip them with employees who have the necessary qualities to successfully work in chosen profession, and the creation of a system that allows them to maintain and develop their working capacity, as well as reliability. To accomplish such tasks, periodic control of the employee's functional status and the identification of objective criteria that characterize the qualitative composition of such units and bodies are necessary. And there is also a need for staff selection.The article examines the system of personnel selection. An analysis of the effectiveness of the existing selection system is carried out.

The important tasks of professional psychological selection are the assessment of the development of the individual-psychological qualities and properties of the applicant's personality, that are necessary for successful training and activities in the chosen specialty, as well as the conclusion on eligibility for training or practical activities in the relevant specialty.Measures to improve the personnel selection system are developed.The foreign experience of selection of personnel is estimated. However, copying of foreign methods of work with personnel without taking into account the characteristics of Ukrainian enterprises can have a significant negative effect - both economic and psychological. Since the mentality, traditions, peculiarities of the spiritual and socio-economic environment in which the person has grown and formed are of great importance in the work with people.The article states that professional and highly skilled personnel selection will have the subsequently positive affect on the reduction of staff turnover, greater employee satisfaction with the service and, as a result, greater efficiency of the organization.

Key words: personnel selection, staff hiring, technology of personnel management, personnel management, HR department, personnel reserve.

The problem presentation in general terms and its connection with important scientific and practical tasks. In a market economy, the staff quality is the most important factor determining the survival and economic situation of Ukrainian companies. That is why the careful personnel selection guarantees the quality of human resources, which largely determines the possibility and effectiveness of their further use. The work of any company is connected with the necessity of staffing. Hereby the personnel selection is considered as one of the most important functions of management, because it is people who ensure the effective use of any kinds of resources available in the company, and its economic performance and competitiveness are in ultimately dependings on people.

An analysis of the latest research and publications that initiated the solution to the problem. Problems of selection of personnel are considered in the works of V. Bakumenko, L. Gogina, V. Dyatlov, M. Ivashov, A. Kibanov, V. Kutsenko, V. Loznitsa, P. Nazymko, M. Snitchuk, A. Turchinov, V. Travin, V. Chuguevsky. They consider the concept of personnel selection as a professional selection of candidates. All spectra of potential human capabilities and characteristics are important for professional selection, so different methods need to be used to identify these opportunities.

At the same time, no studies have been carried out that would either characterize the complex or reflect the optimal selection system.

The purpose of the article. Investigation of the personnel selection system of the organization, analysis of the effectiveness of the existing selection system, development of measures for its improvement, assessment of foreign experience in personnel selection.

Presentation of the main research material. Personnel selection is an extremely important and multifaceted process of studying the professional and psychological qualities of an employee, which determines his ability to perform duties at a particular workplace or position and, ultimately, the choice of a broad set of applicants best one suited to his specialty, qualification, abilities and interests necessary for the goals of the organization / enterprise.

In general, there are many personnel selection technologies. Of course, not every organization practices all stages, because it takes a lot of time and costs. Some stages are presented at the same time, but the more important the vacant position is, the more necessary is using of all stages.

The enterprise or organization is guided by several principles in the personnel selection. The first one is to focus on the strengths rather than on the weaknesses of the person and the search of not ideal, but the most suitable candidates for this position. Moreover, this search would be stopped if several people were unable to meet the requirements imposed on them, because most likely the requirements themselves are overestimated and need to be reviewed. 
Another principle is to ensure compliance with the requirements of the content of work, individual qualities of the applicant: education, seniority, experience, and in some cases gender, age, health, psychological state. If an enterprise needs a new employee, then external means are used (publication of ads on the Internet, access to employment agencies) or personnel selection is through an internal set.

In order to choose the most suitable employee for this position, an enterprise analyzes the workplace. His goal is to: identify which psychological requirements a candidate must meet. After that, a portrait of an ideal employee is making, the characteristics of which fully meet the requirements of the workplace. The next stage is to select a candidate, which will work with maximum efficiency and will feel comfortable in this work.

Staff hiring begins with a detailed definition of who is needed Traditionally, in the basis of this process is the preparation of a job description. In order to facilitate the selection, the agroholding «Mriya» has created, in addition to the job description, documents describing the main characteristics that an employee must have in order to succeed in this position - qualification cards and personal profiles. Personnel selection in the agroholding «Mriya» begins with the formation of requirements for candidates. Requirements for applicants for vacant positions are developed in accordance with the Guide to the qualification characteristics of the professions of employees, the needs of the enterprise and are fixed and regulated by job descriptions. It is accompanied by a definition of the purpose and the formulation of a number of questions to applicants for vacancies. The main rules of final selection at the enterprise are: the selection of employees who are most suitable for the company; ensuring effects over costs; maintaining staff stability while simultaneously attracting new employees; improvement of the moral and psychological climate.

The process of personnel selection at the agroholding «Mriya» is guided by the following principles: the connection of the search and selection of personnel with the strategy and purpose of the organization; scientific and methodological support (labor market research, development and use of personnel selection technology); financial support (substantiation, planning and receipt of financial resources for personnel recruitment); material and technical support (premises, means of office equipment for the processing and recording of information); legal support (strict use of a sound legal basis: labor legislation, all-Ukrainian classification of posts and professions, tariff-qualifying directories); ensuring a fair approach to the evaluation of all candidates for job position; confidentiality (selection and recruitment under conditions of confidentiality, non-disclosure of information about candidates not involved in staff hiring to other enterprises and organizations, and outsiders).

Consequently, the definition of the criteria by which personnel selection should be carried out is an important step in the personnel management, since it allows us to formulate a portrait of the future employee, as well as the main professional and business qualities that the applicant must possess. Due to these indicators, the effectiveness of the selection process and the factors influencing it become clear.

The goal would be achieve only in the case of successful selection of a candidate's position, whose personal and professional qualities are most consistent with this post, its effective motivation and development.

Improvement of the personnel management system at Ukrainian enterprises should be based on accumulated foreign experience. This means, first of all, the generalization of borrowed by the leaders of organizations and enterprises of foreign advanced experience in the field of state financing and stimulation of intra-firm training, selection and recruitment, the using of modern personnel assessment systems, the formation and application of a system of material incentives for various categories of workers to highly effective work, and involvement of a significant part of the personnel in the management of production (affairs of the firm) also.

Personnel selection specialists have the opportunity to study the experience of foreign countries and companies, as well as to apply successfully tested results in practice. The USA can be considered As important example in this matter, because it is this state that is "pioneer" in many aspects of personnel management. Personnel policy in USA companies is usually based on more or less the same principles in the following areas. American companies that use traditional recruitment principles focus on specialized knowledge and professional skills.

There is an orientation towards the narrow specialization of both managers and engineers and scientists in American companies. American experts are mainly professionals in the narrow field of knowledge, that's why their promotion through the management hierarchy occurs only vertically, which means that the financier will only pursue a career in this field. It somewhat limits the possibility of advancement in the stages of management, which determines the fluidity of managerial personnel, their transition from one firm to another.

The Japanese human resources management system differs significantly from the American and Ukrainian ones, since it is based primarily on the mentality of its employees. The first difference is the 
personnel selection.

The HR departments of companies in Japan, as a rule, start to work with students - future specialists when they are still studying at universities. The organization hires employees once a year. At the end of the academic year, graduates make a written examination in an organization that is designed to be able to assess the professional training and the general level of the candidate. Those who have passed the exam are interviewed with the company's management.

The staff turnover in France is much lower than Ukrainian one; therefore, mainly graduates are employed, which the company then «raises» to the required professional and official level [4].

The using of recruitment technologies in foreign firms is a few steps ahead, compared with domestic ones. There is lack of the relevant regulatory framework in Ukraine, as well as the support of employees from the leaders. The experience of the leading companies in the world in human resources management, in particular selection, is important for the development of Ukraine's innovation management. Sufficient provision of organizations with emploees who have the necessary knowledge and skills, rational use of them, high level of labor productivity are important for increasing the volume of production, as well as increasing the efficiency of production.

One of the main problems in the formation of human resources is the definition and application of personnel technologies. The influence on labour potential is exercised with the help of personnel technologies. Today, during the selection of candidates for a vacant position, shot methods are used which do not give an effective result. As a result, there is an urgent need to review the methods of personnel selection, justification for the introduction of innovative selection methods.

The whole range of potential features and characteristics of a person is important for professional selection, which is why it is necessary to apply all possible methods for their definition.

In this regard, the company has developed and approved the "Draft improvement of the personnel selection system of the agroholding «Mriya».

The purpose of the project is to improve the system of selection of the main (basic) staff of the agroholding «Mriya», which will improve the quality of selection, and thus the quality of the base staff [5]. The objectives of the project are to reduce the total time spent per day on interviewing the recruitment manager with candidates for a post, to increase the time spent on interviewing one post-candidate to 30 minutes, and thus: to improve the quality of selection of candidates for the basic (basic) specialties; reduce staff turnover by $4 \%$, reduce the cost of selecting key personnel by reducing staff turnover; increase sales revenue. «Mriya»:

Also important are the recommendations for improving the staff selection system of the agriholding

1. It is difficult to determine the risk of hiring an employee until received full information about its characteristics from the previous job. We must encourage the applicant to be honest. If it seems that applicant is hiding something, then one should try to check it by asking for advice from the former job, or use the services of private agencies. These measures will prevent court proceedings through the disclosure of someone else's trade secrets.

2. It is extremely important to identify in a timely manner the specific inclinations and hidden motivation of the candidate. Based on this, the following recommendations would be useful: to carefully check the documents certifying a person and a permanent or local residence permit; to require recommendations and feedback from previous jobs (suspect applicants who refuse to inform the address and phone from previous jobs); one must take into account the person's tendency to harmful habits (alcohol, drugs, gambling); use information databases (perhaps the applicant has already «lit up» somewhere like a petty thief or a big crook); it is imperative to check for convicted availability of a person (especially for money-grubbing crimes) and even for committing administrative offenses (it is possible that this is an evil hooligan, an alcoholic or a drug addict one).

Practice shows that have to refuse in employment up to $30 \%$ of applicants only for formal reasons.

3. It is necessary to develop a portrait of an ideal employee for each vacancy. Personnel specialist and Deputy Director for Legal and Personnel Affairs should take part in the process. It is the portrait of an ideal employee that will greatly facilitate the process of staff selection for a vacant position. In developing of it, all requirements for candidates must be grouped into three ones: professionalism (education, work experience, professional skills), social competence (family status, teamwork, value system), compliance with corporate culture (assuming the presence in potential employee of those specific qualities that are necessary for the effective particular unit operation). Compared with other requirements, professionalism is placed the highest, since it is believed that if a person is a professional, then his personality disadvantages have less effect on the efficiency of work and on relationships with the team. A professional portrait must be created taking into account both full details of the position, the main and additional responsibilities, and the people with whom the specialist will interact. 
Recommendations to increase the loyalty of agriholding «Mriya» personnel are as follows: during the hiring of employees, it is necessary to propose to sign an agreement on the non-disclosure of information that they became known during the work at the company, and also after release. Psychologically, it works very well: most people are afraid of violating the signed arrangements. It is important that this document specifies a term for the keeping of official secrets; regular use of technical means for recognition of employees' dishonesty (lie detectors, other devices and apparatus); keep track of all information flows and activities of individual employees with increased access to information; track relationships in the team, looking for dissatisfied and insulted employees. They can issue secrets simply «for evil» or for reasons of principle; make public the facts of disclosing of commercial secrets by former employees both inside of the company and in the outside market; to take measures for economic security and employee loyalty.

Conclusions. Consequently, there are some problems with personnel selection at most of Ukrainian enterprises, as well as at the agriholding «Mriya», but in the future, it is expected to improve the quality of this process, which will lead either to improved labor quality or to increase profitable activity.

A prerequisite for the successful implementation of an improved recruitment system is the support from management - in the end, support is even more important than the development of subtle and complex assessment methods or procedures.

In order to improve the situation with the personnel selection it is necessary to adopt some methods and methods from foreign countries in Ukraine. For example, as in Japan - the recruitment of personnel is based on agreements with universities. In France, this process takes place through a well-developed system with an individual approach to each employee.

A professional and highly skilled personnel selection will eventually have a positive impact on the reduction of staff turnover, employee satisfaction with the work and, as a result, on the effectiveness of the organization.

\section{Jimepamypa}

1. Баб'як Г. До питання про можливості застосування зарубіжного досвіду організації формування персоналу в Україні /Г. Баб'як //Регіональні аспекти розвитку продуктивних сил України: науковий журнал. Вип. 21. - Тернопіль: Економічна думка, 2016. - С. 92-97.

2. Баб'як Г. Відбір персоналу як елемент системи технологій управління персоналом /Г. Баб'як //Регіональні аспекти розвитку продуктивних сил України: науковий журнал. Вип. 20. - Тернопіль: Економічна думка, 2015. - С. 114-120.

3. Качан С. П. Забезпечення кадрами - запорука ефективної діяльності промислових підприємств регіону /С. П. Качан //Міжнародна науково-практична конферениія «Проблеми ефективного використання професійно-технічної підготовки кадрів промислового сектору економіки Украӥни». T. 2. - Київ, 2008. - С. 129 132.

4. Особенности управления персоналом во Франции: - [Електронний ресурс] - Режсим доступу: http://t4b.narod.ru...

5. Проект вдосконалення системи відбору персоналу агрохолдингу «Мрія», 2017.

6. Система отбора персонала в США. - [Електронний ресурс]. - Режим доступy: http://globalteka.ru

7. Тюльпанов А. Зарубежный опыт управления персоналом/А. Тюльпанов//Управление персоналом. - 2008. - №19- C. 43.

8. Illiash I. Modern methodical approaches to design the HR-management system of enterprises /Irina Illiash //Scientific and educational periodical jornal «The Genesis of Genius». - Geneva, Switzerland, December 2015. - \#5. Volume 1. - p. 147. - P. 21-23. 